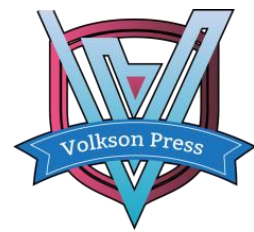

Contents List available at VOLKSON PRESS

DOI : http://doi.org/10.26480/icie.01.2017.67.70

Journal Homepage: : https://www.intelcomp-design.com/

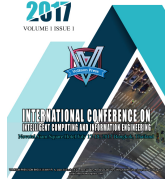

\title{
INNOVATION R\&D, OVERCONFIDENCE AND CORPORATE PERFORMANCE OF GEM LISTED COMPANIES
}

Liu Lan ${ }^{1 *}$, Zhang Xinyao², Shen Ying ${ }^{2}$

${ }^{1}$ Chungnam National University, Korea

${ }^{2}$ Yanbian University, China

*Corresponding author email: lynnliu29@163.com

This is an open access article distributed under the Creative Commons Attribution License, which permits unrestricted use, distribution, and reproduction in any medium, provided the original work is properly cited

\section{ARTICLE DETAILS}

\section{Article History:}

Received 12 May2017

Accepted 12 July 2017

Available online 14 September 2017

Keywords:

Innovation R\&D, Overconfidence, Corporate Performance.

\section{ABSTRACT}

Based on modern housekeeper theory, innovation theory and endogenous variable theory, this paper takes 468 GEM listed companies during 2012-2015 as research samples, and adopts multiple linear regression model to analyze the relationship between managers' overconfidence, innovation input and corporate performance. The empirical results show that: (1) manager's overconfidence affects enterprise's investment decision-making, overconfident managers tend to invest in innovation. (2) Manager's overconfidence and innovation investment have a significant interaction. (3) There is a negative correlation between manager's overconfidence and corporate performance. (4) Enterprise innovation input and corporate performance show a U-type relationship, as when the enterprise innovation input reaches a certain point, enterprise innovation input will no longer bring great performance promotion to the enterprise.

\section{Introduction}

This paper introduces the psychological characteristics of managers' overconfidence, and explains the process of manager's behavior decision from the perspective of managers' irrational factors. Innovation activities represent a special investment behavior [1]. This paper will analyze the relationship between manager's overconfidence and their innovative investment behavior from "irrational psychological" point of view, to answer whether company's innovation input will promote corporate performance [2]

\section{THEORETICAL ANALYSIS AND RESEARCH ASSUMPTIONS}

\subsection{Manager's Overconfidence and Corporate Performance}

Managers are prone to overconfidence when making financial decisions, that is, underestimating the risks of the projects they face, overestimating their ability to deal with problems, and thinking that they have the ability to collect information unachievable to others, and corporate performance as a result of financial decision will also be affected [3]. Overconfident managers are more concerned about information increasing their confidence, and automatically ignore those will weaken their confidence. They are more inclined to rely on experience, intuition, rather than a rational analysis of investment projects. The irrational decision-making makes the company fall into low efficient state, and even fall into a crisis [4]. Based on this, the following hypothesis is made:

H1: There is a negative correlation between executive overconfidence and corporate performance.

\subsection{Manager's Overconfidence and Innovation Input}

Innovation input, as an important business's investment decision-making, will also be affected by manager's overconfidence. Different from the agency theory regarding that managers will be "short-sighted" and "self-interest-centered", modern housekeeper theory holds that there is "selfless agency relationship" between managers and shareholders, as managers are willing to take risks and challenges to invest in R\&D activities, and actively create opportunities to improve corporate performance. Meanwhile, overconfident managers will actively search for innovation opportunities and create profit points for enterprises to achieve their own value. Based on this, the following hypotheses are made:

H2: Executive overconfidence and corporate innovation input are positively correlated.

H3: There is a significant interaction between manager's overconfidence and innovation input.

\subsection{Innovation Input and Corporate Performance}

Based on the theory of endogenous variables and innovation theory, technological innovation and knowledge accumulation are the source of power for enterprise profits. Enterprises must increase their investment in R \& D and innovation activities to avoid diminishing marginal income and eventually form core competitiveness to maintain long-term stable operation. However, with the increase of innovation input, benefits of innovation input will diminish, and after corporate performance reaches the highest point, corporate performance decreases with the increase in innovation in put. Therefore, the following hypothesis is made: 


\section{RESEARCH DESIGN}

\subsection{Sample Screening and Data Sources}

This paper selects GEM listed companies during 2012-2016 as the research sample. In order to ensure accuracy of the study, this paper excludes the following data: (1) companies with missing data and abnormalities; (2) companies receiving ST, * ST, PT; (3) financial listed companies; (4) companies that do not disclose R \& A; (5) companies that do not disclose executive compensation. All data are from the CSMAR database, and a total of 468 data are obtained after screening. Data processing software is SPSS16 and EXCEL.

\subsection{Variable Settings}

\subsubsection{Dependent Variable}

Existing main indicators to measure corporate performance include the following: return on equality (ROE), total return on assets (ROA), Tobin Q, principal business return on assets (CROA), earnings per share (EPS), return on sales (ROS), etc. This paper uses total return on assets (ROA) as a proxy variable for corporate performance.

\subsubsection{Independent Variable}

Overconfidence (OC) variables are measured in the following ways: method of quantity change of shareholding, CEO relative compensation method, number of mergers and acquisitions, media evaluation method, profit forecasting method. In this paper, relative compensation method is used to measure overconfidence, $\mathrm{OC}=$ top three executive compensation / sum of all executive compensations.

\subsubsection{Mediating Variable}

The mediating variable in this paper is the enterprise innovation input, $\mathrm{RD}=\mathrm{R} \& \mathrm{D}$ expenses / operating income.

\subsubsection{Control Variable}

The control variables selected in this paper include: asset-liability ratio (lev), corporate growth (growth), firm size, cash flow (CF), equity concentration (H1).

Table 1: Variable Definition Table

\begin{tabular}{|c|c|c|c|}
\hline Variable type & $\begin{array}{l}\text { Variable } \\
\text { name }\end{array}$ & Variable meaning & Calculation method \\
\hline $\begin{array}{l}\text { Dependent } \\
\text { variable }\end{array}$ & ROA & total return on assets & Net profit / total assets \\
\hline $\begin{array}{l}\text { Dependent } \\
\text { variable }\end{array}$ & $\mathrm{OC}$ & Overconfidence & top three executive compensation / sum of all executive compensations \\
\hline Mediating variable & $\mathrm{RD}$ & $\begin{array}{l}\text { Enterprise innovation } \\
\text { input }\end{array}$ & R \& D expenses / operating income \\
\hline \multirow[t]{2}{*}{ Control variable } & $\begin{array}{l}\text { Lev } \\
\text { Growth }\end{array}$ & $\begin{array}{l}\text { asset-liability ratio } \\
\text { corporate growth }\end{array}$ & $\begin{array}{l}\text { Total liabilities at the end of the period / total assets at the end of the period } \\
\text { (This year's operating income - last year's operating income) / last year's operating } \\
\text { income }\end{array}$ \\
\hline & $\begin{array}{l}\text { Size } \\
\text { CF }\end{array}$ & $\begin{array}{l}\text { firm size } \\
\text { cash flow }\end{array}$ & natural logarithm of the total assets at the end of the period \\
\hline
\end{tabular}

\subsection{Research Model}

Based on the above analysis, the research model of this paper is as follows:

$\mathrm{ROA}=\beta 0+\beta 1 *$ Size $+\beta 2 *$ Growth $+\beta 3 * \mathrm{Lev}+\beta 4 * \mathrm{CF}+\beta 5 * \mathrm{OC}+\beta 7 * \mathrm{RD}+\beta 8 * \mathrm{RD} 2+\beta 9 * \mathrm{OC} * \mathrm{RD}+\varepsilon$

$\mathrm{RD}=\beta 0+\beta 1 *$ Size $+\beta 2 *$ Growth $+\beta 3 * \mathrm{Lev}+\beta 4 * \mathrm{CF}+\beta 5 * \mathrm{OC}+\varepsilon$

\section{EMPIRICAL TEST AND ANALYSIS}

\subsection{Descriptive and Correlation Analysis}

Table 2: Descriptive Statistics and Correlation Analysis of Sample Companies

\begin{tabular}{|c|c|c|c|c|c|c|c|c|c|}
\hline Variable & ROA & $\mathrm{OC}$ & $\mathrm{RD}$ & LEV & Growth & Size & $\mathrm{CF}$ & Mean value & standard deviation \\
\hline ROA & 1 & & & & & & & 0.051 & 0.049 \\
\hline OC & $-0.46^{* * *}$ & 1 & & & & & & 0.302 & 0.269 \\
\hline $\mathrm{RD}$ & $-0.090^{* *}$ & $0.139^{* * *}$ & 1 & & & & & 0.070 & 0.280 \\
\hline LEV & $-0.272^{* *}$ & -0.043 & $0.169^{* *}$ & 1 & & & & 0.247 & 0.153 \\
\hline Growth & 0.286 & 0.028 & 0.053 & 0.048 & 1 & & & 0.317 & 0.516 \\
\hline Size & $0.015^{* * *}$ & -0.118 & $0.141^{* *}$ & $0.288^{* * *}$ & -0.021 & & & 21.116 & 0.698 \\
\hline $\mathrm{CF}$ & 0.399 & -0.026 & 0.071 & -0.179 & -0.073 & -0.053 & 1 & 0.028 & 0.064 \\
\hline
\end{tabular}

A descriptive statistical analysis of the sample companies is shown in Table 2. The mean value of ROA (an indicator to measure performance) is 0.051 and the standard deviation is 0.049 , indicating that the performance level of the sample companies is still to be improved. Wherein, mean value of OC (an indicator to measure overconfidence) is 0.302 , and the standard deviation is 0.269 , indicating that executive overconfidence level of the sample companies is low. For innovation input RD, mean value of the sample companies is 0.070 , and the standard deviation is 0.280 , indicating that R \& $\mathrm{D}$ investment of the sample companies is not ideal. In this paper, we use Pearson simple correlation coefficient as a measure of degree of correlation between variables. The greater correlation coefficient indicates strong dependency between variables. If the correlation coefficient is greater than 0.75 , there may be a collinearity 
problem due to high similarity, so all variables need to undergo correlation analysis before regression analysis. The correlation coefficient in this paper is less than 0.75 , indicating that there is no serious collinearity between the variables of this study.

\subsection{Multiple Regression Analysis}

This paper studies the relationship between manager's overconfidence, innovation input and corporate performance. Using SPSS16.0 as statistical analysis software, multiple linear regression test is adopted for the theoretical model established in this paper. In this paper, control variable is introduced by model 1 , regression analysis with corporate performance ROA is carried out to test whether the control variables are significant and effective. Control variables and $\mathrm{OC}$ and RD are introduced by model 2, regression analysis with ROA is carried out to test the negative correlation between manager's overconfidence and corporate performance in hypothesis (1). OC * RD interaction items and RD2 are introduced in model 3 to test the relationship between innovation input and corporate performance in hypothesis (4), and significant interactions between innovation input and manager's overco nfidence in hypothesis (3). Model 4 tests the positive correlation between manager's overconfidence and innovation input in hypothesis (2).

Table 3: Regression Analysis Results of Manager's Overconfidence, Innovation Input and Corporate Performance

\begin{tabular}{|c|c|c|c|c|}
\hline & \multicolumn{3}{|c|}{ dependent variable is ROA } & \multirow{2}{*}{$\begin{array}{c}\text { dependent variable is RD } \\
\text { Model } 4\end{array}$} \\
\hline & Model 1 & Model 2 & Model 3 & \\
\hline $\begin{array}{l}\text { Constant } \\
\text { Size }\end{array}$ & $\begin{array}{c}(-4.218)^{* * *} \\
0.241^{* * *} \\
(5.782)\end{array}$ & $\begin{array}{c}(-4.092)^{* * *} \\
0.233 \\
(5.310)\end{array}$ & $\begin{array}{c}(-3.781)^{* * *} \\
0.217 \\
(5.223)\end{array}$ & $\begin{array}{c}(3.586) \\
-0.113 \\
(4.152)\end{array}$ \\
\hline Growth & $\begin{array}{c}-0.121 \\
(-0.021)\end{array}$ & $\begin{array}{c}-0.130 \\
(-0.028)\end{array}$ & $\begin{array}{c}0.117 \\
(0.029)\end{array}$ & $\begin{array}{l}-0.016 \\
(0.044)\end{array}$ \\
\hline Lev & $\begin{array}{l}-0.348^{* * *} \\
(-7.761)\end{array}$ & $\begin{array}{l}-0.367^{* * *} \\
(-8.293)\end{array}$ & $\begin{array}{l}-0.367^{* * *} \\
(-8.912)\end{array}$ & $\begin{array}{l}0.482^{* * *} \\
(6.534)\end{array}$ \\
\hline $\mathrm{CF}$ & $\begin{array}{c}-0.181 \\
(-2.910)\end{array}$ & $\begin{array}{c}-0.129 \\
(3.012)\end{array}$ & $\begin{array}{c}0.141 \\
(3.658)\end{array}$ & $\begin{array}{c}0.018 \\
(1.336)\end{array}$ \\
\hline OC & & $\begin{array}{l}-0.298^{* * *} \\
(-13.219)\end{array}$ & $\begin{array}{l}-0.319^{* * *} \\
(-10.281)\end{array}$ & $\begin{array}{l}0.179^{* * *} \\
(7.890)\end{array}$ \\
\hline $\mathrm{RD}$ & & $\begin{array}{l}-0.291^{* * *} \\
(-7.182)\end{array}$ & $\begin{array}{l}-0.485^{* * *} \\
(-5.910)\end{array}$ & \\
\hline RD2 & & & $\begin{array}{l}0.461^{* * *} \\
(4.092)\end{array}$ & \\
\hline $\mathrm{OC} * \mathrm{RD}$ & & & $\begin{array}{l}0.328^{* * *} \\
(-7.918)\end{array}$ & \\
\hline Adj R2 & 0.144 & 0.176 & 0.194 & 0.239 \\
\hline $\mathrm{F}$ & 7.272 & 7.952 & 9.197 & 8.440 \\
\hline
\end{tabular}

Note: $\mathrm{N}=468,{ }^{* * *}$ indicates $\mathrm{p}<0.001,{ }^{* *}$ indicates $\mathrm{p}<0.05,{ }^{*}$ indicates $\mathrm{p}<0.1$, what's in brackets are $\mathrm{T}$ values

From the regression analysis results in Table 3 , it can be seen that correlation coefficient of OC and ROA is negative, $\beta=-0.298$, which is significantly effective at the $1 \%$ confidence level, so hypothesis 1 is validated. In model 3 , correlation coefficient between OC* RD interaction item and ROA corporate performance is negative, which indicates that manager's overconfidence will weaken the effect of enterprise innovation R \& D input on corporate performance, so hypothesis 3 is effectively supported. At the same time, in model 3, between RD2 and ROA, $\beta=0.461, p<0.1$, so hypothesis 4 is verified. Model 4 tests the relationship between manager's overconfidence and innovation input alone, $\beta=0.179, p<0.1$, so hypothesis 2 is validly tested.

\section{RESEARCH CONCLUSION AND DISCUSSION}

Since the executive ladder theory was put forward, more and more research scholars began to pay attention to effect of executive characteristics on company's decision-making and results. Different from the previous research scholars who study the effect of executive heterogeneity on corporate performance from executive qualifications, age, gender characteristics, this paper proceeds from behavioral finance and bounded rationality hypothesis point of view, studies psychological characteristic of managers - overconfidence, to explore the impact of manager's overconfidence on corporate investment decisions.

This paper verifies the hypothesis by correlation analysis: manager's overconfidence affects the enterprise's investment decision-making; overconfident managers will tend to invest in innovation. There is a negative correlation between manager's overconfidence and corporate performance. Manager's overconfidence and innovation investment have a significant interaction which affects corporate performance. Enterprise innovation input and corporate performance show a U-type relationship, as when the enterprise innovation input reaches a certain point, corporate performance will no longer increase.

The results of this study have positive significance in related research and management practice: (1) From the perspective of "irrational person", this paper focuses on the psychological factor of executive overconfidence, and further expands the study on manager's overconfidence and corporate performance, providing new empirical evidence for behavioral finance. (2) Enterprises should avoid inefficient, impair investment which undermines corporate performance caused by manager's overconfidence as they overestimate the project's future rate of return and underestimate project risk. (3) Enterprise should pay attention to the U-type influence of innovation input on corporate performance, make innovation input according to the enterprise situation and avoid damage to corporate performance caused by lack of innovation input and excessive innovation input.

Deficiencies of this paper: This paper discusses the impact of interaction between executive overconfidence and innovation input on corporate performance, but does not discuss whether innovation decisions made due to executive overconfidence can lead to innovation performance.

\section{REFERENCES}


[1] Ying, H., Xing, L., Zhaonan, L. 2015. Empirical Study on Overconfidence and Investment Decision of Senior Executives in Listed Companies in China. Chinese Journal of Management Science, 13 (5), 142-148.

[2] Jingtao, Y., Xiuping, Z., Huacheng, W. 2015. Enterprise heterogeneity, executive overconfidence and enterprise innovation performance. Innovation Management, 18 (6), 101-112.

[3] Tienan, W., Yu, W. 2017. Information technology investment, CEO overconfidence and corporate performance. Business Review, 29 (1), $70-81$

[4] Haiming, W., Deming, Z. 2012. Study on the Influence of Overconfidence on Investment Behavior of Enterprises Based on the perspective of CEO's rights regulation. Journal of Hunan University (Natural Science Edition), 39 (11), 99-03. 